Article

\title{
Understanding the Effects of Parameter Uncertainty on Temporal Dynamics of Groundwater-Surface Water Interaction
}

\author{
Gopal Chandra Saha ${ }^{1,2, *}$, Jianbing $\mathrm{Li}^{2}$ and Ronald W. Thring ${ }^{2}$ \\ 1 Institute for Environmental Sustainability, Mount Royal University, Calgary, AB. T3E 6k6, Canada \\ 2 Environmental Engineering Program, University of Northern British Columbia, Prince George, \\ B.C. V2N 4Z9, Canada; Jianbing.Li@unbc.ca (J.L.); Ron.Thring@unbc.ca (R.W.T.) \\ * Correspondence: gsaha@mtroyal.ca; Tel.: +1-403-440-8809
}

Academic Editor: Abdon Atangana

Received: 29 March 2017; Accepted: 8 May 2017; Published: 12 May 2017

\begin{abstract}
This study presents the understanding of temporal dynamics of groundwater-surface water (GW-SW) interaction due to parameter uncertainty by using a physically-based and distributed gridded surface subsurface hydrologic analysis (GSSHA) model combined with a Monte Carlo simulation. A study area along the main stem of the Kiskatinaw River of the Kiskatinaw River watershed, Northeast British Columbia, Canada, was used as a case study. Two different greenhouse gas (GHG) emission scenarios (i.e., A2: heterogeneous world with self-reliance and preservation of local identities, and B1: a more integrated and environmental-friendly world) of the Special Report on Emissions Scenarios (SRES) from the Fourth Assessment Report of the Intergovernmental Panel on Climate Change (IPCC) for 2013 were used as case scenarios. Before conducting uncertainty analysis, a sensitivity analysis was performed to find the most sensitive parameters to the model output (i.e., mean monthly groundwater contribution to stream flow). Then, a Monte Carlo simulation was used to conduct the uncertainty analysis. The uncertainty analysis results under both case scenarios revealed that the pattern of the cumulative relative frequency distribution of the mean monthly and annual groundwater contributions to stream flow varied monthly and annually, respectively, due to the uncertainties of the sensitive model parameters. In addition, the pattern of the cumulative relative frequency distribution of a particular month's groundwater contribution to the stream flow differed significantly between both scenarios. These results indicated the complexities and uncertainties in the GW-SW interaction system. Therefore, it is of necessity to use such uncertainty analysis results rather than the point estimates for better water resources management decision-making.
\end{abstract}

Keywords: parameter uncertainty; groundwater-surface water interaction; Monte Carlo simulation

\section{Introduction}

Groundwater-surface water (GW-SW) interaction plays a vital role in the functioning of riparian ecosystems [1]. During wet periods, surface water can recharge groundwater, but during dry periods groundwater can act as an important source to feed the surface water flow. As a result, groundwater and surface water are closely-linked components of the hydrologic system due to their interdependency to each other. The development and exploitation of any one component can affect the other. Therefore, for developing sustainable water resources management, it is crucial to understand and quantify the exchange processes between these two components [2]. During the last decade, many researchers have used different hydrologic models to quantify these exchange processes. For instance, Scibek and Allen [3] used the coupled Hydrologic Evaluation of Landfill Performance (HELP) and visual MODular three-dimensional finite-difference groundwater FLOW (MODFLOW) 
model; Van Roosmalen et al. [4] used the DK model (The National Water Resource model for Denmark); Goderniaux et al. [5] used the HydroGeoSphere model; Stoll et al. [6] used the MIKE Système Hydrologique Européen (MIKE-SHE) model; Jackson et al. [7] used the coupled Zoom Object-Oriented Distributed Recharge Model (ZOODRM) and Zoom Object-Oriented Quasi-3-Dimensional Model (ZOOMQ3D); Vansteenkiste et al. [8] used the MIKE-SHE, and Water and Energy Transfer between Soil, Plants and Atmosphere (WetSpa) models; El Hassan et al. [9] used the Gridded Surface Subsurface Hydrologic Analysis (GSSHA) model; Wu et al. [10] used Groundwater and Surface-water FLOW (GSFLOW) model; Faramarzi et al. [11] used the Soil and Water Assessment Tool (SWAT) model. Most of the parameters (e.g., soil properties, surface roughness) in hydrologic models used for GW-SW interaction simulations require intensive field measurements [12], and they are always associated with uncertainty. Such uncertainty could also lead to uncertainty in modeling outputs [13], which could jeopardize the decision-making of water resources management. The uncertainty analysis could provide a range of outputs instead of one output, and enable the watershed manager to take proper action with respect to water withdrawal from the river, and allocation to the stakeholders for future water supply depending on the month and season.

Due to the importance of parameter uncertainty in hydrologic models, many researchers used different uncertainty analysis methods in different hydrologic models to conduct uncertainty analysis of modeling outputs during the last several decades. For example, Beven and Binley [14] used the Generalized Likelihood Uncertainty Estimation (GLUE) method in the Institute of Hydrology Distributed Model (IHDM) to investigate how the stream flow hydrograph varies under the parameter uncertainty during a number of storms in the Gwy catchment, Wales. Kuczera and Mroczkowski [15] assessed the use of multinormal approximation to parameter uncertainty for the exploration of multiresponse data (i.e., stream flow, stream chloride concentration, groundwater level) in the CATPRO hydrosalinity model in the Wights catchment in Western Australia. Vrugt et al. [16] used the Markov Chain Monte Carlo (MCMC) method in the HYdrological MODel (HYMOD) to find out the variation of stream flow under the parameter uncertainty in the Leaf River watershed, Mississippi, USA. Benke et al. [12] used the Monte Carlo simulation (MCS) method as an uncertainty analysis method in the $2 \mathrm{C}$ hydrological model to investigate the impacts of parameter uncertainty on the prediction of stream flow in Eastern Australia. Mishra [17] used the first-order second-moment (FOSM) and MCS methods in the Natural Systems Regional Simulation Model (NSRSM) to compare the impacts of parameter uncertainty on stream flow prediction in Southern Florida, USA. Shen et al. $[18,19]$ used GLUE and MCS methods, respectively, in the SWAT model to quantify the effects of parameter uncertainty on stream flow and sediment in the Daning River watershed of the Three Gorges Reservoir Region, China. Wu et al. [10] used the Probabilistic Collocation Method (PCM) in the GSFLOW model for integrated modeling of GW-SW systems (i.e., annual stream flow, annual GW-SW exchange, and annual groundwater level) in the Heihe River Basin, China. Fan et al. [20] used PCM and MCS methods in the HYMOD to compare the uncertainty of stream flow predictions due to the parameter uncertainty in the Xiangxi River basin of the Three Gorges Reservoir Region, China. Fan et al. [21] used the Hybrid Sequential Data Assimilation and Probabilistic Collocation (HSDAPC) method in the HYMOD for analyzing uncertainty of stream flow predictions due to the parameter uncertainty in the Xiangxi River basin of the Three Gorges Reservoir Region, China. Wu et al. [22] used CoupModel combined with the GLUE method to investigate the water and energy balance in seasonally-frozen soils due to parameter uncertainty in Northern China. Faramarzi et al. [11] used multivariate uniform distribution in the SWAT model to assess uncertainty of freshwater scarcity in semi-arid watersheds of Alberta, Canada. However, there is little knowledge regarding the uncertainty analysis of mean monthly (i.e., intra-annual) and annual groundwater contributions to stream flow due to parameter uncertainty in a watershed. The objective of the study was to understand and find out the variation of the mean monthly and annual groundwater contributions to stream flow due to parameter uncertainty. These contributions information will be useful in determining the temporal status of groundwater resources and site conditions for groundwater-dependent terrestrial ecosystems [23]. They will also 
determine the temporal variations of stream flow dependency on groundwater, and these will provide useful information for both short and long-term water withdrawal from the river and water supply decision-making. This study also presents a new technique to understand temporal dynamics of GW-SW interaction systems by using temporal mean groundwater contributions to the stream flow. A GSSHA hydrologic model was developed for this study in a study area along the main stem of the Kiskatinaw River of the Kiskatinaw River watershed (KRW) in Northeastern British Columbia, Canada. The A2 and B1 greenhouse gas (GHG) emission scenarios of SRES (Special Report on Emissions Scenarios) of the Intergovernmental Panel on Climate Change (IPCC) of 2013 were used as case scenarios. Before conducting uncertainty analysis, a sensitivity analysis was conducted to find out the most sensitive parameters to the model outputs. Then Monte Carlo realizations of the most sensitive modeling parameters were generated for the GSSHA model to conduct the uncertainty analysis of the temporal dynamics of the GW-SW interaction.

\section{Study Area}

The Kiskatinaw River watershed (KRW) is a multi-use watershed located in Northeast British Columbia, Canada, as shown in Figure 1. The KRW provides water for drinking water supply and household activities, timber harvesting, oil and gas, agriculture, wildlife, recreation, and mineral resources. The City of Dawson Creek has been using water from Kiskatinaw River for drinking purpose since the mid-1940s because of the presence of high total hardness in groundwater of this region [24]. The water demand in the KRW increased significantly after 2005 because of shale gas exploration/production activities. The large scale of shale gas exploration/production, timber harvesting, and agricultural activities in recent years have resulted in water conflicts among various water users.

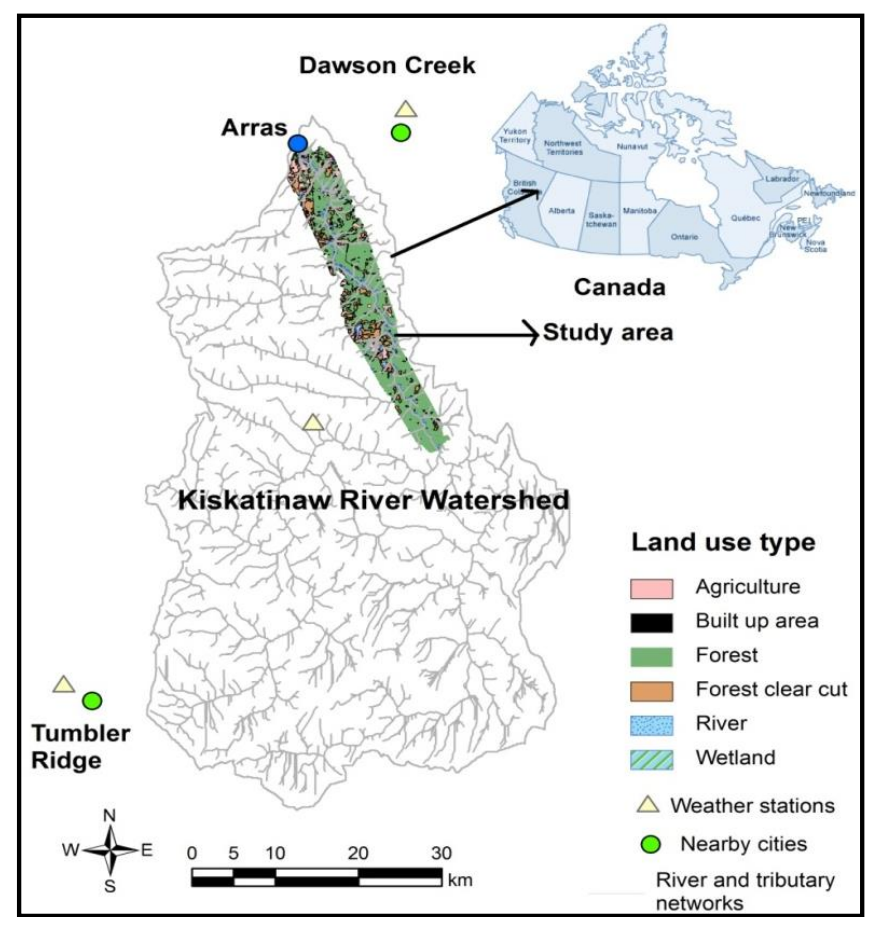

Figure 1. Land use map of the study area and its location in the Kiskatinaw River Watershed, as well as in Canada.

The study area $\left(213.82 \mathrm{~km}^{2}\right)$ is situated along the main stem of the Kiskatinaw River in the KRW (Figure 1). The City of Dawson Creek's drinking water intake of the water supply system is located at Arras in the study area. The elevation of the study area ranges from $687 \mathrm{~m}$ to $950 \mathrm{~m}$, and the mean 
slope is $7.8 \%$ [25]. The dominant soil texture in the study area is mainly clay loam (91\%), although silt loam and sandy loam occupy $6 \%$ and $3 \%$ of the study area, respectively. The study area is mainly a forested area (68\%) (Figure 1). Other land use types are forest clear cut $(18.7 \%)$, agriculture $(8 \%)$, wetland $(2 \%)$, water $(1.8 \%)$, and built up area $(1.5 \%)$.

The hydrologic system in the KRW is flashy, with peak flows occurring from late June to early July, but in January the flow drops to $0.052 \mathrm{~m}^{3} / \mathrm{s}$ [24]. The mean annual precipitation and temperature in the KRW is $499 \mathrm{~mm}$, and $2.7^{\circ} \mathrm{C}$, respectively (mean over the period of 2000-2011). The major portion of the precipitation is rainfall $(320 \mathrm{~mm})$, therefore, the hydrologic system in the KRW is rain dominated. Previous studies reported that the river system in the KRW is groundwater dependent $[25,26]$. Therefore, it is very important to conduct an uncertainty analysis of GW-SW interaction in the study area to understand those interactions and develop future water resources management plans.

\section{Materials and Methods}

\subsection{GW-SW Interaction Modeling}

In order to conduct an uncertainty analysis of GW-SW interaction, a physically-based, distributed and structured grid-based GSSHA hydrologic model was developed for the study area. The model domain was discretized into grid cells of $30 \mathrm{~m}$ by $30 \mathrm{~m}$. In GSSHA model, infiltration was computed by using the Green and Ampt infiltration with a redistribution method [27]. Saturated groundwater flow was computed by using a finite difference representation of the following 2-D lateral saturated groundwater flow equation:

$$
\frac{\partial}{\partial x}\left(K_{x} b \frac{\partial h}{\partial x}\right)+\frac{\partial}{\partial y}\left(K_{y} b \frac{\partial h}{\partial y}\right)=S \frac{\partial h}{\partial t}+W(x, y, t),
$$

where $\mathrm{K}_{\mathrm{x}}$ is the hydraulic conductivity of soil in $\mathrm{x}$ direction, $\mathrm{K}_{\mathrm{y}}$ is the hydraulic conductivity of soil in $\mathrm{y}$ direction, $\mathrm{h}$ is the hydraulic head, $\mathrm{S}$ is the storage term, $\mathrm{b}$ is the depth of the saturated media, and $\mathrm{W}$ is the flux term for sources and sinks. Water flux between the stream and the saturated groundwater was estimated by using Darcy's law and the following equation:

$$
f=\frac{K_{s b}}{M_{s b}}\left(E_{g w}-E_{s w}\right)
$$

where $\mathrm{f}$ is the flux between the stream and the saturated groundwater, $\mathrm{K}_{\mathrm{sb}}$ is the hydraulic conductivity of the streambed material, $\mathrm{M}_{\mathrm{sb}}$ is the depth of the streambed material, $\mathrm{E}_{\mathrm{gw}}$ is the elevation of groundwater surface, and $\mathrm{E}_{\mathrm{sb}}$ is the elevation of stream water surface. Groundwater discharge was then calculated by multiplying this $\mathrm{f}$ by the top width and length of the channel segment. Overland flow was simulated by using the Alternating Direction Explicit (ADE) finite difference method, while channel flow was simulated by using an explicit solution of the diffusive wave equation. The details of GSSHA can be found from Downer [28].

The GSSHA model requires a number of inputs, such as watershed specific data (i.e., elevation, channel geometry, soil type, and land use/land cover), hydrological (i.e., stream flow, and groundwater level) data, and climate (i.e., precipitation and temperature) and meteorological (i.e., wind speed, relative humidity, barometric pressure, direct and global radiations) data. The details of these data for this study were listed in Table 1. In this study, width and length of the channel segment were assumed constant. Observed hourly climate and meteorological data of three nearby weather stations were averaged by an arithmetic method to obtain daily distribution of those parameters for 2000-2011. In addition, in this study the soils of the study area were assumed as isotropic because the stratification of the soil layers of the study area were not available. Since GSSHA is a grid-based model, three index maps were prepared for assigning parameters at the grid level. One is a land use index map, and others are a soil type index map and a combined land use and soil type index map. In addition, 
initial groundwater table and aquifer (unconfined) bottom maps were prepared by using the inverse distance weighted (IDW) interpolation method. The distance between ground elevation and aquifer bottom elevation was used to make the vertical layer of the modeling domain. A similar approach was used by Woldeamlak et al. [32] in their developed model for investigating GW-SW interaction. The barometric pressure correction was estimated as per the technical guidelines of Solinst [33] to correct the groundwater table data because groundwater table fluctuates by atmospheric pressure with altitude change [34]. Around the perimeter of the study area, no-flow boundary condition was chosen for the developed model based on previous studies results [35]. In addition, the flux river boundary condition was chosen for the stream because of the significant exchange between groundwater and the stream network. Then the model was calibrated using Shuffled Complex Evolution method (automated calibration). Due to the limited observed stream flow data, the model calibration was conducted for the time period from 15 October 2010 to 31 December 2011. A simulation time step of 1 min was used for calibration and validation based on the temporal convergence study of observed and simulated stream flows at the outlet of the study area. There was flood in the KRW in 2011, and the model calibration was conducted to evaluate the performance of the model during flooding year. During calibration (Figure 2a), $\mathrm{R}^{2}$ (coefficient of determination) $=0.67$, and NSE (Nash-Sutcliffe efficiency) $=0.62$ were obtained. Santhi et al. [36] and Van Liew et al. [37] suggested an acceptable model evaluation when $\mathrm{R}^{2}$ value of greater than 0.5 obtained. These evaluation statistics criteria indicated satisfactory GSSHA model calibration. The calibrated parameters were tabulated in Table 2. Model validation was performed for the time period from 15 October 2006 to 15 October 2010, and this time period was normal annual precipitation years. The modeling validation results (Figure $2 b$ ) presented $R^{2}=0.63$, and NSE $=0.58$. Therefore, satisfactory model validation was also achieved. During calibration and validation periods, the flow direction was from groundwater to surface water, which indicates gaining stream or groundwater discharging to the stream.

Table 1. Details of input data for GSSHA model development.

\begin{tabular}{|c|c|c|}
\hline Data Type & Data and Format & Source \\
\hline Watershed & $\begin{array}{l}\text { - Canadian Digital Elevation Data of } \\
\text { - } \quad \text { Channel geometry } \\
\text { - } \quad \text { Land use/land cover of } 30 \mathrm{~m} \text { by } 30 \mathrm{~m} \\
\text { grid for year } 2010 \\
\text { - Soil }\end{array}$ & $\begin{array}{ll}\text { - } & \text { Geo Base of Natural Resources } \\
& \text { Canada [29] } \\
\text { - } & \text { Field survey and Google maps } \\
\text { - } & \text { Paul [30] } \\
\text { - } & \text { Soil survey report of Land } \\
& \text { Resource Research Institute [31], } \\
& \text { and Saha [25] }\end{array}$ \\
\hline Hydrological & $\begin{array}{l}\text { - } \quad \text { Daily stream flow from } 2006 \text { to } 2011 \\
\text { - } \quad \text { Groundwater level }\end{array}$ & $\begin{array}{l}\text { - } \quad \text { Water Survey of Canada station } \\
\text { Groundwater monitoring network } \\
\text { in the KRW }\end{array}$ \\
\hline $\begin{array}{l}\text { Climate and } \\
\text { Meteorological }\end{array}$ & $\begin{array}{l}\text { Observed hourly precipitation and } \\
\text { temperature and other meteorological } \\
\text { data (i.e., relative humidity, wind } \\
\text { speed, barometric pressure, direct and } \\
\text { global radiations) from } 2000 \text { to } 2011\end{array}$ & $\begin{array}{l}\text { - Three weather stations from } \\
\text { British Columbia Ministry of } \\
\text { Forests, Lands and Natural } \\
\text { Resources Operations }\end{array}$ \\
\hline
\end{tabular}



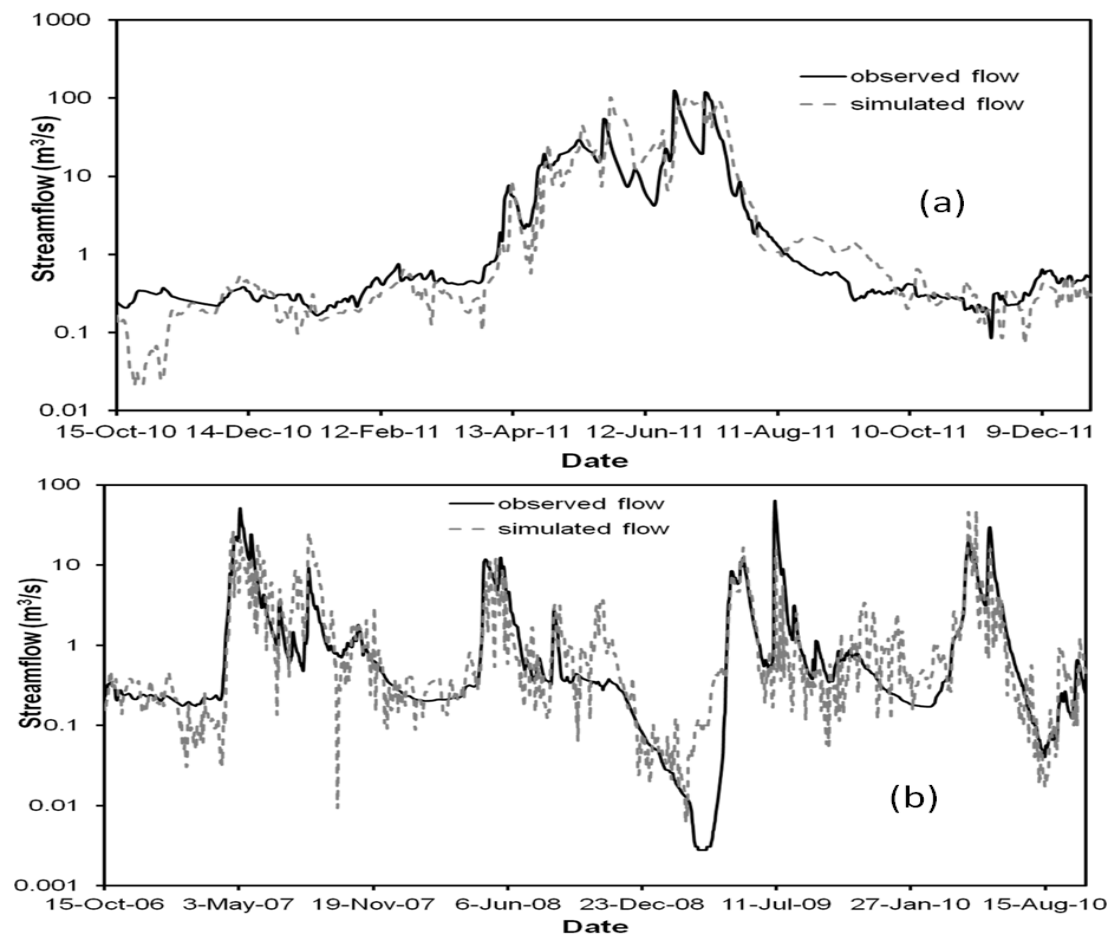

Figure 2. Observed and simulated stream flows by the GSSHA model at the outlet of the study area during (a) calibration and (b) validation periods.

Table 2. Calibrated parameters' values used in the GSSHA model. Here GW means groundwater.

\begin{tabular}{|c|c|c|c|}
\hline Process & Process Parameter & Unit & Value \\
\hline Infiltration and GW & $\begin{array}{l}\text { Saturated hydraulic conductivity (Ks) } \\
\text { (clay loam-forest) }\end{array}$ & $\mathrm{cm} / \mathrm{hr}$ & 0.15 \\
\hline Infiltration and GW & Ks (clay loam-built-up area) & $\mathrm{cm} / \mathrm{hr}$ & 0.03 \\
\hline Infiltration and GW & Ks (clay loam-forest clear cut area) & $\mathrm{cm} / \mathrm{hr}$ & 0.08 \\
\hline Infiltration and GW & Ks (clay loam-agriculture) & $\mathrm{cm} / \mathrm{hr}$ & 0.10 \\
\hline Infiltration and GW & Ks (clay loam-wetland) & $\mathrm{cm} / \mathrm{hr}$ & 0.05 \\
\hline Infiltration and GW & Ks (sandy loam-forest) & $\mathrm{cm} / \mathrm{hr}$ & 0.93 \\
\hline Infiltration and GW & Ks (sandy loam-forest clear cut area) & $\mathrm{cm} / \mathrm{hr}$ & 0.34 \\
\hline Infiltration and GW & Ks (sandy loam-agriculture) & $\mathrm{cm} / \mathrm{hr}$ & 0.42 \\
\hline Infiltration and GW & Ks (silt loam-forest clear cut area) & $\mathrm{cm} / \mathrm{hr}$ & 0.7 \\
\hline Infiltration and GW & Ks (silt loam-forest) & $\mathrm{cm} / \mathrm{hr}$ & 0.81 \\
\hline Infiltration and GW & Ks (silt loam-built-up area) & $\mathrm{cm} / \mathrm{hr}$ & 0.09 \\
\hline Infiltration & Initial moisture (clay loam) & - & 0.21 \\
\hline Infiltration & Initial moisture (silt loam) & - & 0.15 \\
\hline Infiltration & Initial moisture (sandy loam) & - & 0.11 \\
\hline Overland flow & Manning's n (built-up area) & - & 0.011 \\
\hline Overland flow & Manning's n (agriculture) & - & 0.035 \\
\hline Overland flow & Manning's n (forest) & - & 0.1 \\
\hline Overland flow & Manning's n (forest clear cut area) & - & 0.03 \\
\hline Infiltration and GW & Porosity (silt loam) & - & 0.501 \\
\hline Infiltration and GW & Porosity (clay loam) & - & 0.464 \\
\hline Infiltration and GW & Porosity (sandy loam) & - & 0.453 \\
\hline Channel flow & Manning's n (river) & - & 0.025 \\
\hline Soil moisture & Soil moisture depth & $\mathrm{m}$ & 0.5 \\
\hline GW-stream & Ks (stream bed material) & $\mathrm{cm} / \mathrm{hr}$ & 1.1 \\
\hline GW-stream & Stream bed material's thickness & $\mathrm{cm}$ & 15 \\
\hline Retention & Retention depth (agriculture) & $\mathrm{mm}$ & 0.1 \\
\hline Retention & Retention depth (forest) & $\mathrm{mm}$ & 0.12 \\
\hline Retention & Retention depth (forest clear cut area) & $\mathrm{mm}$ & 0.1 \\
\hline
\end{tabular}

\subsection{Generation of Case Scenarios}

Two case scenarios were generated to understand and find out the variation of the mean monthly and annual groundwater contributions to stream flow due to parameter uncertainty. Those scenarios were generated by using two climate change scenarios for 2013, which were obtained from CRCM 4.2 
(Canadian Regional Climate Model) modeling outputs of the CCCma (Canadian Centre for Climate Modeling and Analysis). Those scenarios were A2 and B1 GHG emission scenarios of SRES of the IPCC [38]. The A2 scenario was used because it corresponds to regional economic development, and the large-scale shale gas exploration/production activities began in the KRW during 2005, and enhanced regional economy [39]. The B1 scenario was selected because it represents a more integrated and environmental friendly world [38]. These CRCM outputs are monthly means for two GHG emission scenarios [40]. For each scenario, three CRCM outputs were averaged as a mean. A similar approach was applied in various hydrological studies $[3,8]$. Then those outputs were distributed as daily values in the particular month by using the delta change method. This method is a commonly used simple downscaling method to deal with biases when using climate model outputs in hydrological studies at the catchment or sub-watershed scale [41,42]. This method has been used in a number of hydrological impact studies [4,40,43-45]. The details of delta change method can be found in Graham et al. [44], van Roosmalen et al. [4], and van Roosmalen et al. [45].

The temperature outputs from the delta change method showed that the trend of the mean monthly temperatures in 2013 under the A2 and B1 scenarios was similar to those of 2000-2011; with the highest and lowest mean monthly temperatures occurring in July and January, respectively, (Figure 3a). It was also found that the mean monthly temperatures under the A2 scenario were associated with higher values than under the B1 scenario for most of the months, except in July, August, October, and December. The mean annual temperature in 2013 under the A2 and B1 scenarios was $3.29^{\circ} \mathrm{C}$ and $3.05^{\circ} \mathrm{C}$, respectively, which was above by $0.59^{\circ} \mathrm{C}$ and $0.35^{\circ} \mathrm{C}$ as compared to those of 2000-2011, respectively. This variability occurred because of the anthropogenic increases in the atmospheric concentrations of greenhouse gases $[38,46]$.
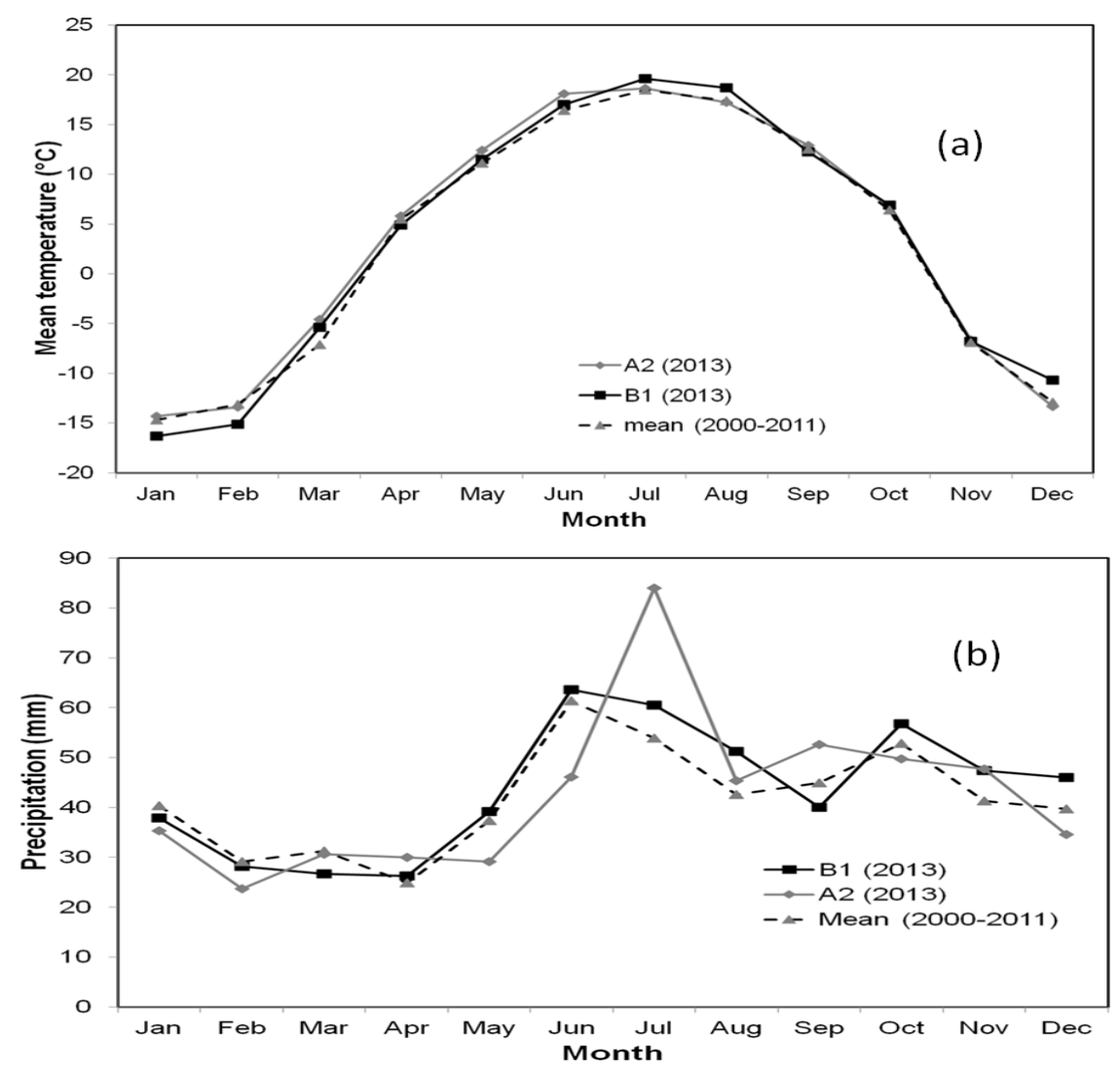

Figure 3. Projected (a) mean monthly temperatures and (b) monthly precipitations under the A2 and B1 scenarios in 2013. 
The precipitation outputs from the delta change method showed that the monthly precipitations of 2013 under the A2 and B1 scenarios had variable patterns (Figure 3b) due to the anthropogenic increases in the atmospheric concentrations of greenhouse gases $[38,46]$. The peak monthly precipitation under the B1 scenario followed the similar trend of the peak mean monthly precipitations of 2000-2011; on the other hand, it followed an opposite trend under the A2 scenario. It was also found that the monthly precipitations were higher in most of the months under the B1 scenario than under the A2 scenario, except in March, April, July, September, and November. The annual precipitation of 2013 under the A2 and B1 scenarios was $509 \mathrm{~mm}$ and $524 \mathrm{~mm}$, respectively, and these numbers were greater than the

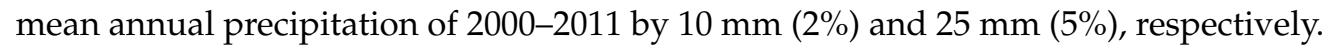

\subsection{Sensitivity Analysis of GW-SW Interaction}

Before conducting the uncertainty analysis of any hydrological model, it is important to conduct a sensitivity analysis of the modeling input parameters because sensitivity analysis indicates the assessment of uncertainty importance [17]. In this study, sensitivity analysis was conducted using the OAT (One-factor-At-a-Time) method [47]. The OAT method was chosen because it is the simplest method for conducting a sensitivity analysis [48], and there were 28 calibrated parameters in the developed GSSHA model which required a large number of numerical runs for conducting the sensitivity analysis using other methods (e.g., factorial design). Using the OAT method, each calibrated parameter was changed by a small amount at a time from a reference (i.e., base) value while keeping the remaining parameters constant, and then the corresponding change in the modeling output (i.e., mean monthly groundwater contribution to stream flow) was computed. The GSSHA model estimates monthly total volume of stream discharge (flow) and groundwater discharge [49], and then the mean monthly groundwater contribution to stream flow was calculated by dividing monthly total volume of groundwater discharge by monthly total volume of stream discharge. This procedure was repeated for three times, and every time the calibrated parameter was increased and decreased by a factor of $20 \%$ of the reference value. Based on these computed changes, relative sensitivity of each parameter was determined by calculating the normalized sensitivity coefficient (NSC) or relative sensitivity coefficient. This sensitivity coefficient is dimensionless and calculated using the following equation:

$$
\mathrm{NSC}=\frac{\left(\mathrm{R}_{\mathrm{a}}-\mathrm{R}_{\mathrm{n}}\right) / \mathrm{R}_{\mathrm{n}}}{\left(\mathrm{P}_{\mathrm{a}}-\mathrm{P}_{\mathrm{n}}\right) / \mathrm{P}_{\mathrm{n}}}
$$

where $P_{a}$ and $R_{a}$ are the parameter's changing value and the model output after a particular model run using the parameter's changing value, respectively, and $P_{n}$ and $R_{n}$ are parameter's base value and the model output after a particular model run using the parameter's base value, respectively. Table 3 lists all of the parameters' relative sensitivities, as well as their sensitivity rankings. Here, relative sensitivity and ranking were evaluated based on the change in the mean monthly groundwater contributions to the stream flow.

Table 3. Calibrated parameters' relative sensitivities and their sensitivity rankings.

\begin{tabular}{llll}
\hline Parameter & Unit & Relative Sensitivity & Rank \\
\hline Manning's n (river) & - & 0.39 & 1 \\
Soil moisture depth & $\mathrm{m}$ & 0.32 & 2 \\
Initial soil moisture (clay loam) & - & 0.29 & 3 \\
Ks (clay loam-forest) & $\mathrm{cm} / \mathrm{hr}$ & 0.24 & 4 \\
Porosity (clay loam) & - & 0.12 & 5 \\
Ks (clay loam-forest clear cut area) & $\mathrm{cm} / \mathrm{hr}$ & 0.08 & 6 \\
Ks (clay loam-agriculture) & $\mathrm{cm} / \mathrm{hr}$ & 0.006 & 7 \\
Ks (sandy loam-forest) & $\mathrm{cm} / \mathrm{hr}$ & 0.0052 & 8 \\
Ks (clay loam-built up area) & $\mathrm{cm} / \mathrm{hr}$ & 0.005 & 9 \\
Ks (clay loam-wetland) & $\mathrm{cm} / \mathrm{hr}$ & 0.003 & 10 \\
Porosity (silt loam) & - & 0.002 & 11 \\
Ks (silt loam-forest) & $\mathrm{cm} / \mathrm{hr}$ & 0.0001 & 12 \\
\hline
\end{tabular}


Table 3 showed that 12 parameters out of 28 calibrated parameters of the developed model had small to large impacts on the modeling outputs. Eleven of these twelve parameters control infiltration and soil moisture, which, in turn control groundwater flow, whereas the other parameter controls stream (i.e., channel) flow routing. Manning's n (river), which controls stream flow routing, had the highest relative sensitivity. Rushton [50] also indicated that, in many regional groundwater model studies, aquifer (i.e., groundwater) to river flows are not very sensitive to changes in the river coefficient (in the GSSHA model, hydraulic conductivity of the streambed material and streambed material's thickness), but only groundwater heads beneath the river show greater influence on the aquifer to river flows. Therefore, the output of sensitivity analysis of this study also supported the findings of Rushton [50]. Two criteria (mean and standard deviation) of the normalized sensitivity coefficients were selected to identify the most sensitive parameters, which influence the modeling outputs [51]. Mean and standard deviation were calculated based on the estimated NSC values of the four runs in the OAT method. Soil moisture depth, initial soil moisture (clay loam), Ks (clay loam-forest), porosity (clay loam), and Ks (clay loam-forest clear cut area) ranked second, third, fourth, fifth, and sixth, respectively, based on their relative sensitivities' values. The parameters (i.e., Ks (clay loam-agriculture), Ks (sandy loam-forest), Ks (clay loam-built up area), Ks (clay loam-wetland), porosity (silt loam), and Ks (silt loam-forest)), ranked from seventh to twelfth, and their changes had very little impact on the change in the mean monthly groundwater contributions to the stream flow, as well as the relative sensitivity because clay loam-agriculture, sandy loam-forest, clay loam-built up area, clay loam-wetland, silt loam, and silt loam-forest occupy $8 \%, 2 \%, 1 \%, 2 \%, 6 \%$, and $6 \%$ of the study area, respectively. As a result, these six parameters (i.e., ranked seventh to twelfth) were not considered for uncertainty analysis in this study. Benke et al. [12] also noted that when parameters have little impact on the modeling output value, they can be easily ignored for simplification of the model structure.

\subsection{Uncertainty Analysis of GW-SW Interaction}

Uncertainty analysis of GW-SW interaction was conducted using the six most sensitive parameters. These input parameters' values were obtained from text books, journals, and other field-collected results conducted by scientific institutes under similar conditions [52-60]. The values of these parameters were assumed to be normally distributed. This distribution was used for these parameters in other studies (e.g., Chen et al. [61] and Cheng et al. [62] for hydraulic conductivity; Le et al. [63] for porosity; Bora and Rajput [58] and Morikawa et al. [64] for Manning's n; Choi and Jacobs [65] for initial soil moisture; and Adams et al. [66] for soil moisture depth). In this study, a Monte Carlo simulation was used as the uncertainty analysis method because it is the most popular reliability-analysis-based stochastic method for evaluating uncertainties in hydrology studies [67]. Table 4 presented all these parameters' mean and standard deviation values which were used for generating Monte Carlo realizations of these parameters based on the assumed probabilistic distributions. Using these realizations, uncertainty analysis of GW-SW interaction was conducted for the A2 and B1 GHG emission scenarios of 2013.

Table 4. Mean and standard deviation values of the most sensitive parameters used for uncertainty analysis.

\begin{tabular}{llll}
\hline Parameter & Unit & Mean & Standard Deviation \\
\hline Manning's n (river) & - & 0.032 & 0.01 \\
Soil moisture depth & $\mathrm{m}$ & 0.60 & 0.125 \\
Initial soil moisture (clay loam) & - & 0.18 & 0.04 \\
Ks (clay loam-forest) & $\mathrm{cm} / \mathrm{hr}$ & 0.20 & 0.08 \\
Porosity (clay loam) & - & 0.45 & 0.02 \\
Ks (clay loam-forest clear cut area) & $\mathrm{cm} / \mathrm{hr}$ & 0.12 & 0.05 \\
\hline
\end{tabular}




\section{Results and Discussion}

\subsection{Uncertainty Analysis of GW-SW Interaction under the A2 Scenario}

The uncertainty analysis results of GW-SW interaction under the A2 GHG emission scenario were analyzed by using the cumulative relative frequency distribution of temporal (i.e., monthly, and annual) groundwater contributions to the stream flow. The results showed that the pattern of the cumulative relative frequency distribution of the mean monthly groundwater contributions to the stream flow varied monthly due to the sensitive modeling parameter uncertainty (Figure 4). It also demonstrated the complexities and uncertainties in the GW-SW interaction system. Table 5 shows the detailed uncertainty analysis results (i.e., range, mean, and standard deviation) of the mean monthly groundwater contributions to stream flow in different months of 2013 under the A2 scenario against the simulated value for the corresponding month using the calibrated parameters' values that were used in model calibration and validation. These results indicated the necessity of using uncertainty analysis in modeling parameters rather than point estimates. The results also illustrated that the output, generated by the calibrated model using the calibrated parameters' values, fell within the range of modeling outputs from uncertainty analysis. It was also found that the calculated highest range (i.e., interval) of the mean monthly groundwater contribution to the stream flow occurred during low flow months in winter (December-February), and early spring (March). During winter and early spring, precipitation occurred mainly as snow in the study area. This snow accumulated, and resulted in low surface runoff before complete snow melt. Therefore, the range of the mean groundwater contribution to the stream flow was higher during winter months. On the other hand, the lowest range of the mean groundwater contribution to the stream flow occurred during summer months (June and July) because higher rainfall during summer resulted in a greater increase of surface runoff $[4,68,69]$ compared to that of groundwater discharge.

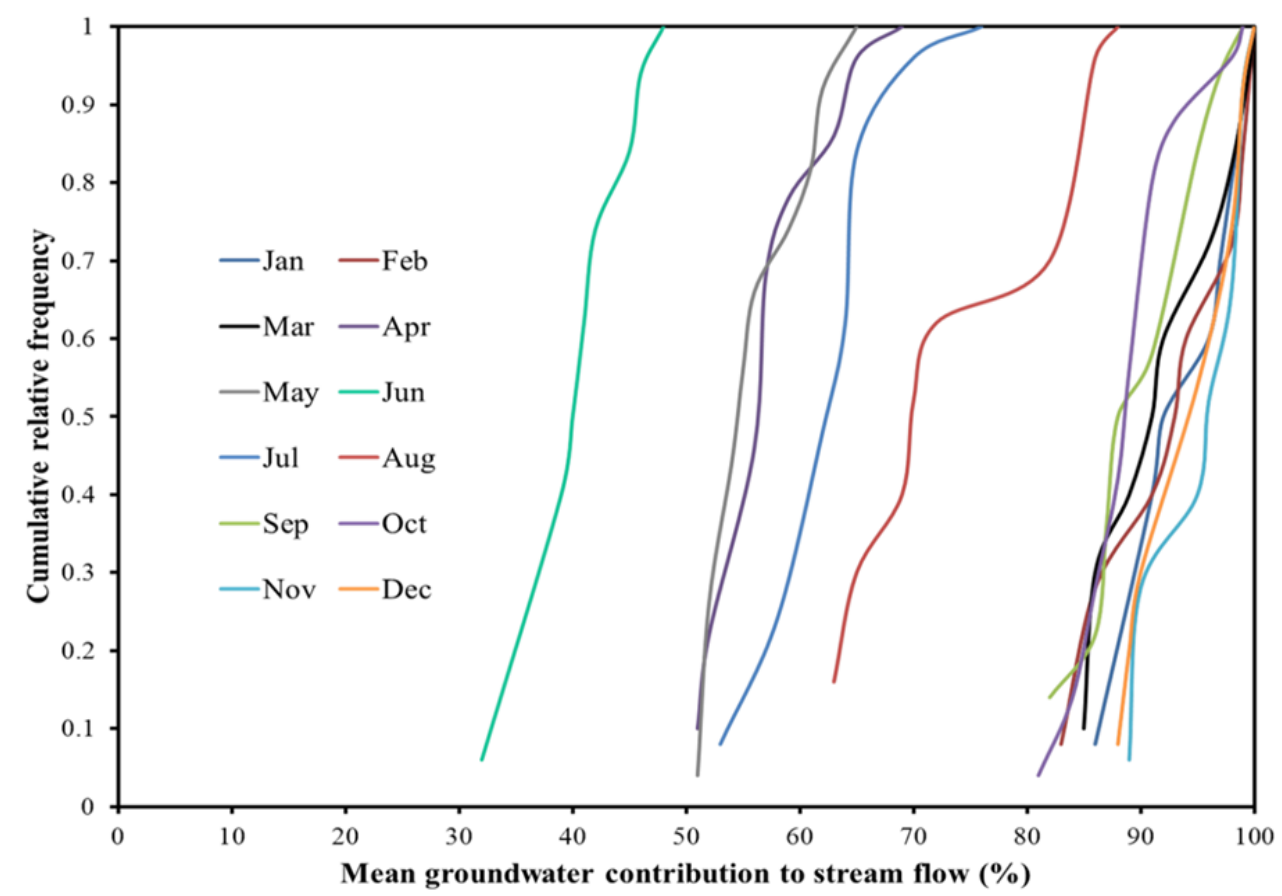

Figure 4. Cumulative relative frequency distribution of mean groundwater contributions to stream flow in different months of 2013 under the A2 GHG emission scenario. 
Table 5. Uncertainty analysis results of mean monthly groundwater contributions to stream flow under the A2 GHG emission scenario in 2013 against the simulated value for corresponding month using the calibrated parameters' values.

\begin{tabular}{ccccc}
\hline Month & $\begin{array}{c}\text { Range of Mean } \\
\text { Groundwater Contribution } \\
\text { to Stream Flow (\%) }\end{array}$ & Mean (\%) & $\begin{array}{c}\text { Standard } \\
\text { Deviation (\%) }\end{array}$ & $\begin{array}{c}\text { Output Using the } \\
\text { Calibrated Parameters' } \\
\text { Values (\%) }\end{array}$ \\
\hline January & $86-100$ & 94.19 & 5.74 & 93.16 \\
February & $83-100$ & 93.22 & 6.32 & 90.79 \\
March & $85-100$ & 92.44 & 5.63 & 93.53 \\
April & $51-69$ & 58.19 & 6.08 & 54.26 \\
May & $51-65$ & 56.78 & 4.71 & 57.23 \\
June & $32-48$ & 41.10 & 4.45 & 44.04 \\
July & $53-76$ & 64.40 & 5.55 & 59.20 \\
August & $63-88$ & 76.76 & 10.01 & 71.89 \\
September & $82-99$ & 90.41 & 6.33 & 88.94 \\
October & $81-99$ & 90.06 & 5.53 & 93.81 \\
November & $89-99$ & 94.73 & 4.35 & 95.90 \\
December & $88-100$ & 95.23 & 4.55 & 97.50 \\
\hline
\end{tabular}

\subsection{Uncertainty Analysis of GW-SW Interaction under the B1 Scenario}

Similar to the A2 scenario, the pattern of the cumulative relative frequency distribution of the mean monthly groundwater contributions to the stream flow under the B1 scenario varied monthly due to the sensitive modeling parameter uncertainty (Figure 5). However, the pattern of the cumulative relative frequency distribution of particular month's groundwater contribution to stream flow differed significantly between both scenarios. This also demonstrated the complex and uncertain characteristics of GW-SW interaction system in watershed. The output of a particular month, generated using the calibrated parameters' values, also fell within the range of the modeling outputs from uncertainty analysis (Table 6). The calculated highest range of mean monthly groundwater contribution to the stream flow also occurred during low flow months in the winter and early spring.

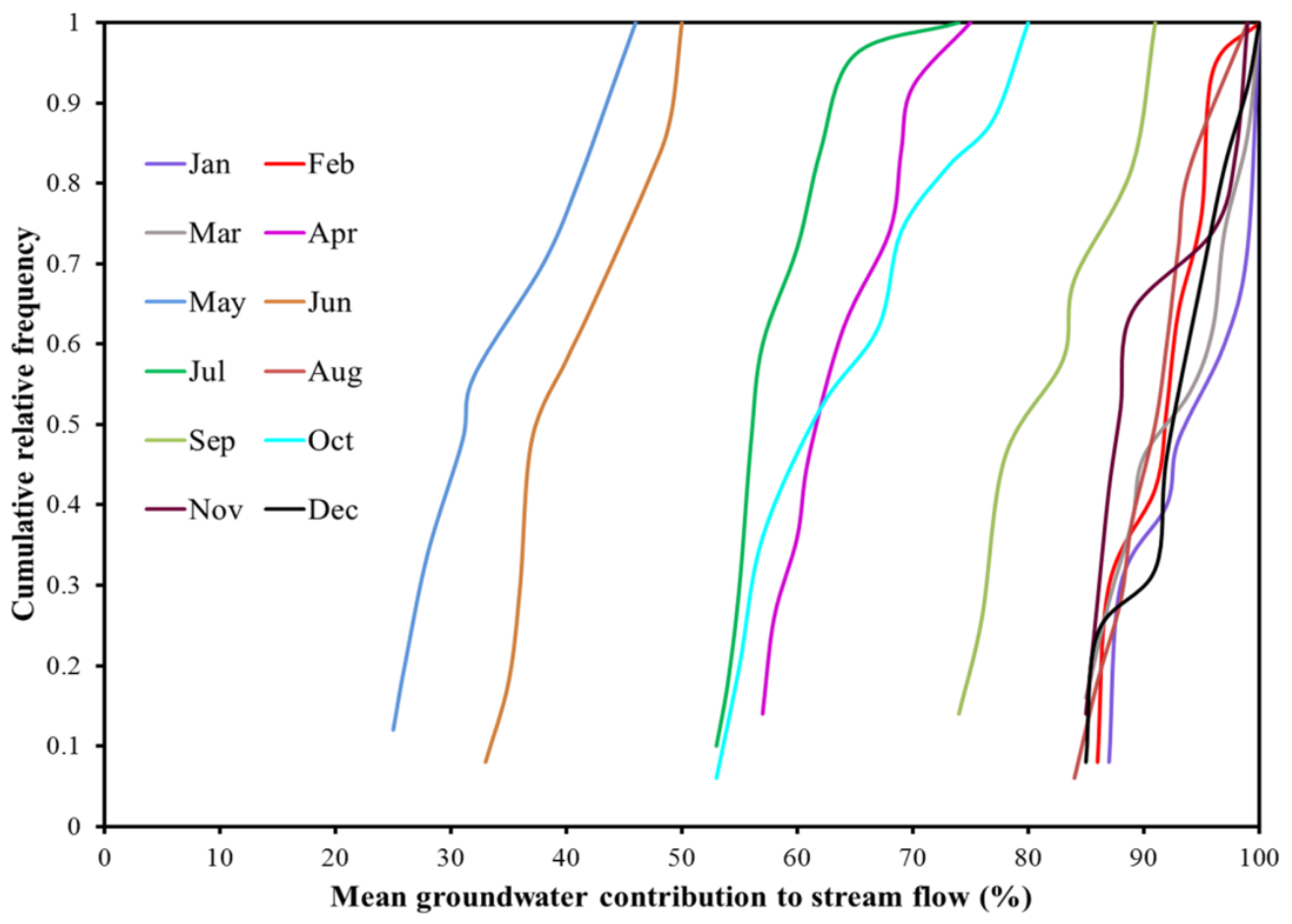

Figure 5. Cumulative relative frequency distribution of mean groundwater contributions to stream flow in different months of 2013 under the B1 GHG emission scenario. 
Table 6. Uncertainty analysis results of mean monthly groundwater contributions to stream flow under the B1 GHG emission scenario in 2013 against simulated value for corresponding month by using the calibrated parameters' values.

\begin{tabular}{ccccc}
\hline Month & $\begin{array}{c}\text { Range of Mean } \\
\text { Groundwater Contribution } \\
\text { to Stream Flow (\%) }\end{array}$ & Mean (\%) & $\begin{array}{c}\text { Standard } \\
\text { Deviation (\%) }\end{array}$ & $\begin{array}{c}\text { Output Using the } \\
\text { Calibrated Parameters' } \\
\text { Values (\%) }\end{array}$ \\
\hline January & $87-100$ & 94.29 & 5.56 & 99.79 \\
February & $86-100$ & 93.53 & 4.94 & 98.32 \\
March & $85-100$ & 93.27 & 5.82 & 98.46 \\
April & $57-75$ & 64.15 & 6.35 & 63.16 \\
May & $25-46$ & 35.67 & 7.97 & 28.30 \\
June & $33-50$ & 41.35 & 6.36 & 47.21 \\
July & $53-74$ & 60.53 & 6.43 & 61.30 \\
August & $84-99$ & 91.64 & 5.19 & 96.20 \\
September & $74-91$ & 81.99 & 6.91 & 87.70 \\
October & $53-80$ & 66.02 & 10.10 & 86.48 \\
November & $85-99$ & 91.15 & 5.49 & 87.82 \\
December & $85-100$ & 92.65 & 5.64 & 97.89 \\
\hline
\end{tabular}

\subsection{Comparison of Uncertainty Analysis of GW-SW Interaction between the A2 and B1 Scenarios}

Figure 6 illustrates the cumulative relative frequency distribution of the mean annual groundwater contribution to stream flow in 2013 under the A2 and B1 scenarios. Similar to the pattern of the cumulative relative frequency distribution of mean monthly groundwater contributions to stream flow, the pattern of the cumulative relative frequency distribution of mean annual groundwater contributions to stream flow under both scenarios varied due to the modeling parameter uncertainty. Under the A2 scenario, the mean annual groundwater contribution to stream flow ranged from $72 \%$ to $87 \%$, with a mean of $79 \%$ and a standard deviation of $4 \%$. On the other hand, the mean annual groundwater contribution to stream flow in 2013 was $78 \%$ using the calibrated parameters' values. Under the B1 scenario, the mean annual groundwater contribution to stream flow ranged from $70 \%$ to $82 \%$, with a mean of $75 \%$ and a standard deviation of $3.5 \%$. On the other hand, the mean annual groundwater contribution to stream flow in 2013 was close to $77 \%$ using the calibrated parameters' values. Compared to the A2 scenario, the range of the mean annual groundwater contributions to stream flow under the B1 scenario was lower. This occurred because more precipitation was predicted under the B1 scenario than under the A2 scenario in 2013. This increased precipitation resulted in surface water and groundwater levels increasing. However, the major increase occurred in surface water levels due to increased surface runoff because of the steep topography of the study area (average slope of $7.8 \%$ ). Therefore, the gradient between the groundwater and surface water was decreased, and resulted in lower range of mean annual groundwater contribution to stream flow under the B1 scenario. It also demonstrated that uncertainty in the mean annual groundwater contribution to the stream flow under the A2 scenario was higher than that in the B1 scenario because of the higher precipitation in the B1 scenario. Therefore, lower uncertainties are associated in GW-SW interaction system during wet years compared to dry years. This reflects the complexities in GW-SW interaction system.

The uncertainty analysis provides a range of outputs instead of one output, and this range of outputs would provide more information to the watershed manager to take particular action with a certain degree of risks regarding water withdrawal from the river and allocation to stakeholders for future water supplies depending on the month and season. However, the range of outputs and prediction would differ from year to year depending on the amount and pattern (i.e., only rainfall or both snow and rainfall) of the annual precipitation. 


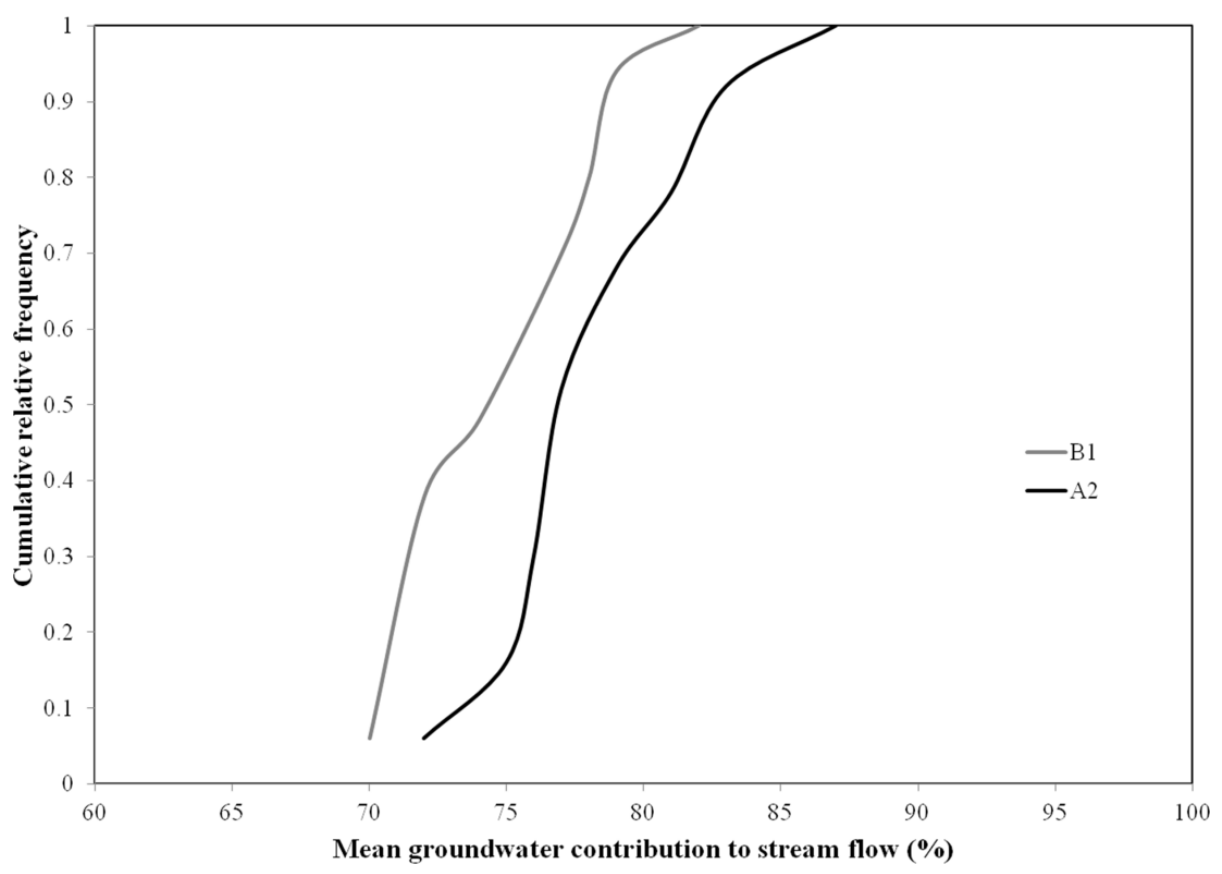

Figure 6. Cumulative relative frequency distribution of mean annual groundwater contributions to the stream flow in 2013 under the A2 and B1 GHG emission scenarios.

\section{Conclusions}

In this study an uncertainty analysis of GW-SW interaction was conducted to understand and determine the variation of temporal (i.e., monthly, and annual) mean groundwater contributions to stream flow due to parameter uncertainty by using a new technique, which was based on temporal mean groundwater contributions to streamflow. The uncertainty analysis results showed that the pattern of the cumulative relative frequency distribution of mean monthly and annual groundwater contributions to stream flow under both case scenarios varied monthly and annually, respectively, because of the uncertainties of the sensitive model parameters. The results also demonstrated that uncertainties in the sensitive parameters had significant effects on the predicted mean monthly and annual groundwater contributions to stream flow. The comparison of two case scenarios also indicated that lower uncertainties are associated in the GW-SW interaction system during wet years compared to dry years. In general, these uncertainty analysis results represent a new way to indicate the complexities and uncertainties in GW-SW interaction system. Therefore, it is very essential to use the uncertainty analysis results for better water resources management decision-making.

Acknowledgments: The authors would like to thank two anonymous reviewers for providing their valuable comments and suggestions, which contributed much to improve the paper. The authors would also like to thank Peter Caputa, Faye Hirshfield, Siddhartho Shekhar Paul, Malyssa Maurer, Reg Whiten, and Chelton van Geloven for their help and support.

Author Contributions: Gopal Chandra Saha and Jianbing Li designed the idea; Gopal Chandra Saha performed the simulation, and analyzed the results; Gopal Chandra Saha, Jianbing Li, and Ronald W. Thring wrote the paper.

Conflicts of Interest: The authors have declared that no competing interests exist.

\section{References}

1. Kalbus, E.; Reinstorf, F.; Schirmer, M. Measuring methods for groundwater-surface water interactions: A review. Hydrol. Earth Syst. Sci. 2006, 10, 873-887. [CrossRef]

2. Sophocleous, M. Interactions between groundwater and surface water: The state of the science. Hydrogeol. J. 2002, 10, 52-67. [CrossRef] 
3. Scibek, J.; Allen, D.M. Modeled impacts of predicted climate change on recharge and groundwater levels. Water Resour. Res. 2006, 42, W11405. [CrossRef]

4. Van Roosmalen, L.; Christensen, B.S.B.; Sonnenborg, T.O. Regional differences in climate change impacts on groundwater and stream discharge in Denmark. Vadose Zone J. 2007, 6, 554-571. [CrossRef]

5. Goderniaux, P. Impact of climate change on groundwater reserves. Ph.D. Thesis, University of Liege, Liège, Belgium, 2010.

6. Stoll, S.; Hendricks Franssen, H.J.H.; Butts, M.; Kinzelbach, W. Analysis of the impact of climate change on groundwater related hydrological fluxes: A multi-model approach including different downscaling methods. Hydrol. Earth Syst. Sci. 2011, 15, 21-38. [CrossRef]

7. Jackson, C.R.; Meister, R.; Prudhomme, C. Modeling the effects of climate change and its uncertainty on UK Chalk groundwater resources from an ensemble of global climate model projections. J. Hydrol. 2011, 399, 12-28. [CrossRef]

8. Vansteenkiste, T.; Tavakoli, M.; Ntegeka, V.; Willems, P.; De Smedt, F; Batelaan, O. Climate change impact on river flows and catchment hydrology: A comparison of two spatially distributed models. Hydrol. Process. 2012. [CrossRef]

9. El Hassan, A.A.; Sharif, H.O.; Jackson, T.; Chintalapudi, S. Performance of a conceptual and physically based model in simulating the response of a semi-urbanized watershed in San Antonio, Texas. Hydrol. Process. 2013, 27, 3394-3408. [CrossRef]

10. Wu, B.; Zheng, Y.; Tian, Y.; Wu, X.; Yao, Y.; Han, F.; Liu, J.; Zheng, C. Systematic assessment of the uncertainty in integrated surface water-groundwater modeling based on the probabilistic collocation method. Water Resour. Res. 2014, 50, 5848-5865. [CrossRef]

11. Faramarzi, M.; Abbaspour, K.C.; Adamowicz, W.L.; Lu, W.; Fennell, J.; Zehnder, A.J.B.; Goss, G.G. Uncertainty based assessment of dynamic freshwater scarcity in semi-arid watersheds of Alberta, Canada. J. Hydrol. Reg. Stud. 2017, 9, 48-68. [CrossRef]

12. Benke, K.K.; Lowell, K.E.; Hamilton, A.J. Parameter uncertainty, sensitivity analysis and prediction error in a water-balance hydrological model. Math. Comput. Model. 2008, 47, 1134-1149. [CrossRef]

13. Muleta, M.K.; Nicklow, J.W. Sensitivity and uncertainty analysis coupled with automatic calibration for a distributed watershed model. J. Hydrol. 2004, 306, 127-145. [CrossRef]

14. Beven, K.J.; Binley, A.M. The future of distributed models: Model calibration and uncertainty prediction. Hydrol. Process. 1992, 6, 279-298. [CrossRef]

15. Kuczera, G.; Mroczkowski, M. Assessment of hydrological parameter uncertainty and the worth of multiresponse data. Water Resour. Res. 1998, 34, 1481-1489. [CrossRef]

16. Vrugt, J.A.; Gupta, H.V.; Bouten, W.; Sorooshian, S. A Shuffled Complex Evolution Metropolis algorithm for optimization and uncertainty assessment of hydrologic model parameters. Water Resour. Res. 2003, 39, 1201. [CrossRef]

17. Mishra, S. Uncertainty and sensitivity analysis techniques for hydrologic modeling. J. Hydroinform. 2009, 11, 282-296. [CrossRef]

18. Shen, Z.Y.; Chen, L.; Chen, T. Analysis of parameter uncertainty in hydrological and sediment modeling using GLUE method: A case study of SWAT model applied to Three Gorges Reservoir Region, China. Hydrol. Earth Syst. Sci. 2012, 16, 121-132. [CrossRef]

19. Shen, Z.Y.; Chen, L.; Chen, T. The influence of parameter distribution uncertainty on hydrological and sediment modeling: A case study of SWAT model applied to the Daning watershed of the Three Gorges Reservoir Region, China. Stoch. Env. Res. Risk 2013, 27, 235-251.

20. Fan, Y.R.; Huang, W.; Huang, G.H.; Huang, K.; Zhou, X. A PCM-based stochastic hydrological model for uncertainty quantification in watershed systems. Stoch. Env. Res. Risk 2015, 29, 915-927. [CrossRef]

21. Fan, Y.R.; Huang, G.H.; Baetz, B.W.; Li, Y.P.; Huang, K.; Li, Z.; Chen, X.; Xiong, L.H. Parameter uncertainty and temporal dynamics of sensitivity for hydrologic models: A hybrid sequential data assimilation and probabilistic collocation method. Environ. Modell. Softw. 2016, 86, 30-49. [CrossRef]

22. Wu, M.; Jansoon, P.; Tan, X.; Wu, J.; Huang, J. Constraining Parameter Uncertainty in Simulations of Water and Heat Dynamics in Seasonally Frozen Soil Using Limited Observed Data. Water 2016, 8, 64. [CrossRef]

23. Naumburg, E.; Mata-Gonzalez, R.; Hunter, R.; Mclendon, T.; Martin, D. Phreatophytic vegetation and groundwater fluctuations: A review of current research and application of ecosystem response modeling with an emphasis on Great Basin vegetation. Environ. Manag. 2005, 35, 726-740. [CrossRef] [PubMed] 
24. Dobson Engineering Ltd.; Urban Systems Ltd. Kiskatinaw River Watershed Management Plan. 2003. File 0714.0046.01. Available online: http://www.dawsoncreek.ca/cityhall/departments/water/watershed/ background-watershed-management-plans/ (accessed on 12 November 2016).

25. Saha, G.C. Groundwater-surface water interaction under the effects of climate and land use changes. Ph.D. Thesis, University of Northern British Columbia, Prince George, BC, Canada, 2014.

26. Saha, G.C.; Paul, S.S.; Li, J.; Hirshfield, F.; Sui, J. Investigation of land-use change and groundwater-surface water interaction in the Kiskatinaw River Watershed, British Columbia (parts of NTS 093P/01, /02, /07-/10) Report 2013-1. In Geoscience BC Summary of Activities 2012; Geoscience BC: Vancouver, BC, Canada, 2013; pp. 139-148.

27. Ogden, F.L.; Saghafian, B. Green and ampt infiltration with redistribution. J. Irrig. Drain. Eng. 1997, 123, 386-393. [CrossRef]

28. Downer, C.W. Identification and modeling of important stream flow producing processes in watersheds. Ph.D. Thesis, University of Connecticut, Storrs, USA, 2002.

29. GeoBase. Available online: www.geobase.ca (accessed on 15 January 2016).

30. Paul, S.S. Analysis of land use and land cover change in Kiskatinaw River watershed: A remote sensing, GIS \& modeling approach. M.Sc. Thesis, University of Northern British Columbia, Prince George, BC, Canada, 2013.

31. Land Resource Research Institute. Soils of Fort St. John-Dawson Creek, British Columbia. Soil Survey report No. 42; Agriculture Canada: Vancouver, BC, USA, 1985.

32. Woldeamlak, S.T.; Batelaan, O.; De Smedt, F. Effects of climate change on the groundwater system in the Grote-Nete catchment, Belgium. Hydrogeol. J. 2007, 15, 891-901. [CrossRef]

33. Solinst. Available online: www.solinst.com (accessed on 20 May 2014).

34. McWhorter, D.B.; Sunada, D.K. Ground-water Hydrology and Hydraulics; Water Resources Publications: Fort Collins, Colorado, USA, 1977.

35. Kala Groundwater Consulting Ltd. Groundwater potential evaluation Dawson Creek. British Columbia. Reference. 2001, R01332-0622. Available online: http://www.dawsoncreek.ca/wordpress/wpcontent/ uploads/watershed/2001DCk_Kala_GWPotential.pdf (accessed on 18 July 2016).

36. Santhi, C.; Arnold, J.G.; Williams, J.R.; Dugas, W.A.; Srinivasan, R.; Hauck, L.M. Validation of the SWAT model on a large river basin with point and nonpoint sources. J. Am. Water Resour. Assoc. 2001, 37, 1169-1188. [CrossRef]

37. Van Liew, M.W.; Arnold, J.G.; Garbrecht, J.D. Hydrologic simulation on agricultural watersheds: Choosing between two models. Trans. ASAE 2003, 46, 1539-1551. [CrossRef]

38. IPCC. IPCC Special Report. Emission Scenarios; Cambridge University Press: Cambridge, UK, 2000; p. 570.

39. British Columbia Ministry of Energy and Mines. The status of exploration and development activities in the Montney Play region of northern BC. 2012. Available online: http:/ /www.offshore-oilandgas.gov.bc. ca/OG/oilandgas/petroleumgeology/UnconventionalGas/Documents/C\%20Adams.pdf (accessed on 19 December 2015).

40. Bergström, S.; Carlsson, B.; Gardelin, M.; Lindström, G.; Pettersson, A.; Rummukainen, M. Climate change impacts on runoff in Sweden - assessments by global climate models, dynamical downscaling and hydrological modeling. Clim. Res. 2001, 16, 101-112. [CrossRef]

41. Hay, L.E.; Wilby, R.L.; Leavesley, G.H. A comparison of delta change and downscaled GCM scenarios for three mountainous basins in the United States. J. Am. Water Resour. Assoc. 2000, 36, 387-398. [CrossRef]

42. Xu, C.Y.; Widen, E.; Halldin, S. Modelling hydrological consequences of climate change -Progress and challenges. Adv. Atmos. Sci. 2005, 22, 789-797. [CrossRef]

43. Andreasson, J.; Bergström, S.; Carlsson, B.; Graham, L.P.; Lindström, G. Hydrological Change - Climate change impact simulation for Sweden. J. Hum. Environ. 2004, 33, 228-234. [CrossRef]

44. Graham, L.P.; Andréasson, J.; Carlsson, B. Assessing climate change impacts on hydrology from an ensemble of regional climate models, model scales and linking methods - a case study on the Lule River basin. Clim. Change 2007, 81, 293-307. [CrossRef]

45. Van Roosmalen, L.; Christensen, J.H.; Butts, M.; Jensen, K.H.; Refsgaard, J.C. An intercomparison of regional climate model data for hydrological impact studies in Denmark. J. Hydrol. 2010, 380, 406-419. [CrossRef] 
46. IPCC. Climate Change 2007: The Physical Science Basis, Contribution of working Group I to the 4th assessment report (AR4) of the Intergovernmental Panel on Climate Change; Cambridge University Press: Cambridge, UK, 2007; p. 996.

47. Saltelli, A. What is Sensitivity Analysis? In Sensitivity Analysis; Saltelli, A., Chan, K., Scott, E.M., Eds.; Wiley: New York, NY, USA, 2000.

48. Hamby, D.M. A review of techniques for parameter sensitivity analysis of environmental models. Environ. Monit. Assess. 1994, 32, 135-154. [CrossRef] [PubMed]

49. Downer, C.W.; Ogden, F.L. Gridded Surface Subsurface Hydrologic Analysis (GSSHA) User's Manual; Version 1.43 for Watershed Modeling System 6.1; U.S. Army Engineer Research and Development Center: Vicksburg, MS, USA, 2006; ERDC/CHL SR-06-1.

50. Rushton, K. Representation in regional models of saturated river-aquifer interaction for gaining/losing rivers. J. Hydrol. 2007, 334, 262-281. [CrossRef]

51. Nejadhashemi, A.P.; Wardynski, B.J.; Munoz, J.D. Evaluating the impacts of land use changes on hydrologic responses in the agricultural regions of Michigan and Wisconsin. Hydrol. Earth Syst. Sci. Discuss. 2011, 8, 3421-3468. [CrossRef]

52. Clapp, R.B.; Hornberger, G.M. Empirical equations for some soil hydraulic properties. Water Resour. Res. 1978, 14, 601-604. [CrossRef]

53. Rawls, W.J.; Brakensiek, R.L.; Saxton, K.E. Estimation of soil water properties. Trans. ASAE 1982, 25, 1316-1320. [CrossRef]

54. Rawls, W.J.; Brakensiek, D.L.; Miller, N. Green-Ampt infiltration parameters from soil data. J. Hydraul. Eng. 1983, 109, 62-70. [CrossRef]

55. Reynolds, W.D.; Drury, C.F.; Yang, X.M.; Fox, C.A.; Tan, C.S.; Zhang, T.Q. Land management effects on the near-surface physical quality of a clay loam soil. Soil Tillage Res. 2007, 96, 316-330. [CrossRef]

56. Minhas, P.S.; Sharma, D.R. Hydraulic conductivity and clay dispersion as affected by application sequence of saline and simulated rain water. Irrig. Sci. 1986, 7, 159-167.

57. Miller, L.L.; Hinkel, K.M.; Nelson, F.E.; Paetzold, R.F.; Outcalt, S.I. Spatial and temporal patterns of soil moisture and thaw depth at barrow, Alaska USA. In Proceedings of the Seventh International Conference on Permafrost, Yellowknife, NT, Canada, 23-27 June 1998. Collection Nordicana No. 55.

58. Bora, P.K.; Rajput, T.B.S. Spatial and temporal variability of manning's $\mathrm{n}$ in irrigation furrows. J. Agric. Eng. 2003, 40, 35-42.

59. Hatch, C.E.; Fisher, A.T.; Ruehl, C.R.; Stemler, G. Spatial and temporal variations in streambed hydraulic conductivity quantified with time-series thermal methods. J. Hydrol. 2010, 389, 276-288. [CrossRef]

60. Saskatchewan Ministry of Agriculture. Irrigation scheduling manual. November 2008. Available online: http:/ / www.agriculture.gov.sk.ca/Default.aspx?DN=288f45ad-5bab-41b1-9878-80acf555e3bf (accessed on 19 May 2013).

61. Chen, X.; Mi, H.; He, H.; Liu, R.; Gao, M.; Huo, A.; Cheng, D. Hydraulic conductivity variation within and between layers of a high floodplain profile. J. Hydrol. 2014, 515, 147-155. [CrossRef]

62. Cheng, C.; Song, J.; Chen, X.; Wang, D. Statistical Distribution of Streambed Vertical Hydraulic Conductivity along the Platte River, Nebraska. Water Resour. Manag. 2011, 25, 265-285. [CrossRef]

63. Le, T.M.H.; Eiksund, G.R.; Strom, P.J. Statistical characterisation of soil porosity. In Safety, Reliability, Risk and Life-Cycle Performance of Structures and Infrastructures; Deodatis, G., Ellingwood, B.R., Frangopol, D.M., Eds.; Taylor \& Francis Group: London, UK, 2013; pp. 5395-5402.

64. Morikawa, H.; Iiyama, K.; Ohori, M. A study of the stochastic properties of auto-correlation coefficients for micrometer data simultaneously observed at two sites. In Applications of Statistics and Probability in Civil Engineering; Faber, M.H., Kohler, J., Nishijima, K., Eds.; Taylor \& Francis Group: London, UK, 2011; pp. 723-727.

65. Choi, M.; Jacobs, J.M. Soil moisture variability of root zone profiles within SMEX02 remote sensing footprints. Adv. Water Res. 2007, 30, 883-896. [CrossRef]

66. Adams, J.R.; Berg, A.A.; McNairn, H. Field leve; soil moisture variability at 6- and 3-cm sampling depths: Implications for microwave sensor validation. Vadose Zone J. 2013, 12. [CrossRef]

67. Lahkim, M.B.; Garcia, L.A. Stochastic modeling of exposure and risk in a contaminated heterogeneous aquifer, 1: Monte Carlo uncertainty analysis. Environ. Eng. Sci. 1999, 16, 315-328. [CrossRef] 
68. Clow, D.W.; Schrott, L.; Webb, R.; Campbell, D.H.; Torizzo, A.; Dornblaser, M. Groundwater occurrence and contributions to stream flow in an Alpine catchment, Colorado Front Range. Groundw.- Watershed Issue 2003, 41, 937-950. [CrossRef]

69. Koeniger, P.; Leibundgut, C.; Stichler, W. Spatial and temporal characterization of stable isotopes in river water as indicators of groundwater contribution and confirmation of modelling results; a study of the Weser river, Germany. Isot. Environ. Health Stud. 2009, 45, 289-302. [CrossRef] [PubMed] 